\title{
A sandwich ELISA to detect VHSV and IPNV in turbot
}

\author{
M. Vázquez Brañas*, J. Coll Morales and A. Estepa‡ \\ * $R$ and $D$ department, ACUIDORO, S.L., Ferrol - La Coruña, Spain ¥Department of \\ Fish Pathology, Virology Section, CIT-INIA, Madrid, Spain
}

\begin{abstract}
The recent demonstration that reared turbot (Scophthalmus maximus $\mathrm{L}$ ) is a natural host for salmonid rhabdoviruses has made their rapid detection relevant to these fish species. A unique protocol to select and use non-competitive monoclonal antibodies (Mabs) for two high-sensitivity sandwich ELISAs has been developed to detect both infectious pancreatic necrosis virus (IPNV) and viral haemorrhagic septicaemia virus (VHSV) in turbot kidney extracts to assess the possibility of using them in field diagnosis. For maximum sensitivity, turbot kidney extracts can be two-fold diluted with high-ionic strength buffers and assayed for the presence of the major viral proteins (VHS rhabdovirus nucleoprotein N/Nx and/or IPN birnavirus protein VP3). The use of control plates coated with irrelevant mouse antibodies (IgG1 and IgG2a) in parallel ELISAs allows for a precise estimation of possible false positives. Turbot kidney extracts with low levels of virus might now be assayed directly without using cell culture, with high precision and in a short time during the acute phase of these viral diseases in reared turbot.
\end{abstract}

KEYWORDS: Turbot (Scophthalmus maximus), Viral diseases, VHSV, IPNV, Mabs, Diagnosis, ELISA

\section{INTRODUCTION}

Some time ago, Castric and De Kinkelin (1984) demonstrated the susceptibility of turbot (Scophthalmus maximus) and sea bass (Dicentrarchus labrax) to VHSV by experimental infections; more recently, Schlotfeldt et al. (1991) reported a natural outbreak among farmed turbot. In addition, IPNV has also been isolated in turbot fry with a $40 \%$ mortality recorded in Norway (Mortensen et al., 1991, pers. comm.), and turbot has been listed as one of its hosts (McAllister, 1988).

Current methods of fish virus diagnosis are based upon cell culture and seroneutralization. These are time-consuming and labour-intensive and in addition can only be performed in well-prepared laboratories. Other serological techniques used for fish virus detection and identification, such as immunofluorescence or immunoblot, have limited application because of either low sensitivity, technical complexity, difficulty of interpretation or need for specialized equipment (McAllister and Schill, 1986; Way and Dixon, 1988). The ELISA technique using polyclonal antibodies (Pabs) have also been adapted to the salmonid rhabdoviruses causing infectious haematopoietic necrosis

\footnotetext{
* Author to whom correspondence should be addressed at: Dept of Animal Production, Centro de Investigaciones Agrarias de Mabegondo, P.O.B. 10, 15080 La Coruña, Spain.

$\ddagger$ Current address: Laboratory of Virology — Fish Pathology, Centro de Alta Seguridad de Valdeolmos-INIA, Valdeolmos, 28130 Madrid, Spain.
} 
(IHN) (Dixon and Hill, 1984) and viral haemorrhagic septicaemia (VHS) (Way and Dixon, 1988). Results were obtained in under $2 \mathrm{~h}$, but sensitivity was a problem. It has been demonstrated that monoclonal antibodies (Mabs) can improve sensitivity of both immunofluorescence and/or ELISA (Mourton et al., 1990; Sanz and Coll, 1993). A sensitivity of $1 \mathrm{ng} \mathrm{ml}^{-1}$ or $0.2 \mathrm{ng} \mathrm{ml}^{-1}$ has been found for VHSV F1 (a reference strain of VHSV) by using Mabs against the G protein (glycoprotein of the spikes in VHSV) (Mourton et al., 1990) or for all VHSV serotypes by using Mabs against the N/Nx proteins (Sanz and Coll, 1993), respectively. Major advantages of ELISA include the possibility of rapidly processing large numbers of samples by using simple equipment (Martínez and Coll, 1987, 1988) and easy and reproducible scale-up (Coll, 1991). An ELISA method to detect all the possible turbot-affecting viruses with high sensitivity would be highly desirable.

Described here is an immunoenzymatic method with a unique protocol to detect the majority of proteins of the IPN and the VHS viruses in turbot kidney extracts by using two non-competitive Mabs in a sandwich ELISA.

\section{MATERIALS AND METHODS}

\section{Viruses}

The viruses most used were VHSV F1 provided by Dr P.E. Vestergard-Jorgensen, and IPNV Sp provided purified by Dr Babin (INIA in Madrid). Other viruses used were described in Domínguez et al. (1991) and Sanz and Coll (1991).

Epithelioma papillosum cyprini (EPC) cells were used throughout the experiments. Cell culture techniques (with RPMI-1640 cell culture medium, Flow, Strathclyde, Scotland), tissue culture infectious dosages (TCID50) and virus purification were performed as described by Basurco and Coll $(1989 \mathrm{a}, \mathrm{b})$. The protein content of purified virus was estimated, both by Coomassie-blue staining of electrophoretically separated viral protein bands and comparison with standard proteins using absorption at $280 \mathrm{~nm}$ with an extinction coefficient of 1 . Virus purity, as calculated from the scan of Coomassieblue stained gel containing electrophoresed protein bands through a Beckman photodensiometer, was about $95 \%$.

\section{Monoclonal antibodies}

The production and characterization of Mabs against VHSV and IPNV (including those used in this work) have been described elsewhere (Babín et al., 1990; Domínguez et al., 1990, 1991; Sanz and Coll, 1991). A summary of the characteristics of the Mabs selected after this work is given in Table 1 .

Ascites were obtained from hybridoma-injected mice by injection of physiological saline (Coll, 1987a). The ascites were clarified by low-speed centrifugation and stored at $-40{ }^{\circ} \mathrm{C}$ until use. The ascites were purified by affinity chromatography over protein ASepharose columns (Pharmacia, Upsala, Sweden). Sample buffer was 1.5 м glycine, $3 \mathrm{~m}$ $\mathrm{NaCl}, \mathrm{pH}$ 8.9. The retained IgG was eluted with $0.1 \mathrm{~m}$ citric acid, $\mathrm{pH}$ 4.9. Eluted fractions were pooled and dialysed against $10 \mathrm{~mm}$ sodium phosphate, $150 \mathrm{~mm} \mathrm{NaCl}$, pH 7.2 (PBS). Purity as tested by gel electrophoresis gave two single Coomassie-blue stained bands at 50 and 24 $\mathrm{kDa}$, respectively. Table 2 shows the yield of Mabs obtained. 
TABLE 1. Characteristics of Mabs selected for sandwich ELISA

\begin{tabular}{|c|c|c|c|c|c|c|}
\hline Virus & Use & Clone & Antigen & Isotype & Blotting $^{a}$ & Type reactivity \\
\hline VHSV & $\begin{array}{l}\text { Solid phase } \\
\text { Conjugate }\end{array}$ & $\begin{array}{l}2 \mathrm{D} 5 \\
2 \mathrm{C} 9\end{array}$ & $\begin{array}{l}\text { VHS-144 } \\
\text { VHS-144 }\end{array}$ & $\begin{array}{l}\text { G1, K } \\
\text { G2a, K }\end{array}$ & $\begin{array}{l}\mathrm{N} / \mathrm{Nx} \\
\mathrm{N} / \mathrm{Nx}\end{array}$ & $\begin{array}{l}F 1, F 2,23.75 \\
F 1, F 2,23.75\end{array}$ \\
\hline IPNV & $\begin{array}{l}\text { Solid phase } \\
\text { Conjugate }\end{array}$ & $\begin{array}{l}2 \mathrm{~A} 1 \\
2 \mathrm{~F} 12\end{array}$ & $\begin{array}{l}\text { IPN-Sp } \\
\text { IPN-Sp }\end{array}$ & $\begin{array}{l}\text { G2a, K } \\
\text { G2a, K }\end{array}$ & $\begin{array}{l}\text { VP3 } \\
\text { VP3 }\end{array}$ & $\begin{array}{l}\text { Sp, Ab, VR299 } \\
\text { Sp, Ab, VR299 }\end{array}$ \\
\hline
\end{tabular}

a the viral protein specificity was defined by immunoblotting (Basurco et al., 1991). All the antibody pairs chosen were specific for a single virus and the sandwich assay was negative for the other. Each pair of Mabs was directed against a different antigenic determinant in the same viral proteins (N/Nx for VHSV and VP3 for IPNV) as defined by competition experiments.

TABLE 2. Yield of Mabs ${ }^{\mathrm{a}}$ from mouse ascites by affinity chromatography over Protein A

\begin{tabular}{lll}
\hline & & \\
Virus & Peroxidase conjugate & Solid phase \\
\hline IPNV & $2 \mathrm{~F} 12$ & $2 \mathrm{~A} 1$ \\
& $6 \mathrm{mg}$ & $5.4 \mathrm{mg}$ \\
VHSV & $2 \mathrm{C9}$ & $2 \mathrm{D} 5$ \\
& $6 \mathrm{mg}$ & $3 \mathrm{mg}$ \\
\hline
\end{tabular}

${ }^{a}$ Amount of Mab in $\mathrm{mg}$ per $2 \mathrm{ml}$ of mouse ascites. Recovery of activity as analysed by indirect ELISA ranged from 41 to $80 \%$ depending on the Mab.

\section{Indirect ELISA}

Ascites, purified Mabs and their conjugates were titrated by ELISA on microtitre wells coated with the purified viruses. Briefly, $1 \mu \mathrm{g}$ of purified virus was added to the wells of polystyrene plates in $100 \mu \mathrm{l}$ of distilled water, dried overnight at $37^{\circ} \mathrm{C}$, washed with washing buffer (described below), dried and stored at $-4{ }^{\circ} \mathrm{C}$ with blue silica gel. The Mabs were diluted in dilution buffer (described below) and $100 \mu$ l added to the wells. After $1 \mathrm{~h}$ incubation and subsequent washing, $100 \mu \mathrm{l}$ of either peroxidase-labelled antimouse IgG (Nordic, The Netherlands) or Mab was added and incubated for $30 \mathrm{~min}$. Colour development is described below.

\section{Peroxidase conjugates: horseradish peroxidase (E.C.1.11.1.7, 1000 units/mg)}

To couple peroxidase to both Mabs (anti-VHSV 2C9 and anti-IPNV 2F12 (Table 1)) by the one-step aged-glutaraldehyde method, $0.7 \mathrm{mg}$ of antivirus $2 \mathrm{C} 9$ and $1 \mathrm{mg}$ of antivirus $2 \mathrm{~F} 12$ (previously purified and dialysed) were mixed with $10 \mathrm{mg}$ and $25 \mathrm{mg}$, respectively, of horseradish peroxidase (E.C. 1.11.1.7, $1000 \mathrm{mg}^{-1}$, RZ/3.3, Boehringer Mannheim), in $1 \mathrm{ml}$ of PBS pH 7.2 and $20 \mu \mathrm{l}$, of $25 \%$ aged glutaraldehyde. After incubation at $37^{\circ} \mathrm{C}$ for 1 or $2 \mathrm{~h}$, respectively, $1 \mathrm{ml}$ of $4 \mathrm{~m}$ glycine in PBS was added and incubated overnight at room temperature. The resulting conjugates had a molar ratio of antibody to peroxidase of 
0.9:1 (Coll, 1987b). Thus, the conditions for coupling of each of the Mabs had to be optimized.

\section{Sandwich enzyme immunoassay}

The sandwich enzyme immunoassay was developed for capture and detection of virus using modifications of previously described methods (Coll, 1988, 1989). Solid phases used were Nunc microtitre polystyrene plates divided in rows of $8 \times 2$ wells (Microwell module F-16 of medium binding capacity). Polystyrene plates were coated with $1 \mu \mathrm{g} / \mathrm{well}$ of antivirus Mab (Tables 1 and 2) in $100 \mu \mathrm{l}$ of distilled water, dried overnight at $37^{\circ} \mathrm{C}$ and blocked by washing with ten-fold diluted dilution buffer (washing buffer, described below).

Thereafter, plates were dried for $2 \mathrm{~h}$ at $37^{\circ} \mathrm{C}$ and sealed with silica gel at $4{ }^{\circ} \mathrm{C}$. Plates coated with mouse IgG1 (to control Mab 2D5) or IgG2a (to control Mab 2A1) (Chemicon Int., Temecula, CA, USA; $1 \mu \mathrm{l}$ IgG1 or IgG2a diluted in $100 \mu \mathrm{l}$ of distilled water: volume per well $100 \mu \mathrm{l} ; 1.12 \mu \mathrm{l} 2 \mathrm{Al}$ diluted in $100 \mu \mathrm{l}$ of distilled water: volume per well $100 \mu \mathrm{l} ; 2.5 \mu \mathrm{l}$ 2D5 diluted in $100 \mu \mathrm{l}$ of distilled water: volume per well $100 \mu \mathrm{l}$ ) were used as negative controls in parallel ELISA. Coated and blocked solid phases were stable for at least 1 month at $4^{\circ} \mathrm{C}$ using the storage conditions described above.

The assay was carried out as follows: $50 \mu \mathrm{l}$ of sample from fish homogenates (10\% $(\mathrm{w} / \mathrm{v})$ in cell culture medium with $2 \%$ foetal calf serum and $20 \mathrm{~mm}$ Hepes) were pipetted into the wells of coated microplates (homogenate dilutions depending upon exponential phase (Fig. 4) to establish, in accordance with the conjugate dilution, how many ng of virus/well there were throughout the entire plate (Fig. 3)) then $50 \mu \mathrm{l}$ of two-fold concentrated dilution buffer (final concentration one-fold: $100 \mathrm{ml}$ PBS ten-fold $\mathrm{pH} 7.4$, $0.24 \mathrm{~mm}$ merthiolate, $5 \mathrm{~g} \mathrm{l}^{-1}$ serum albumin, $4 \mathrm{~g} \mathrm{l}^{-1}$ Tween $20,50 \mathrm{mg} \mathrm{l}^{-1}$ phenol red, $1 \mathrm{~m}$ $\mathrm{NaCl}$, adjusted to $\mathrm{pH} 7.8-8$ ) containing a 125-fold dilution of the conjugate were added. The plates were then incubated for $120 \mathrm{~min}$ at room temperature and washed four times with washing buffer (ten-fold diluted dilution buffer) and once with distilled water. Thereafter, $100 \mu$ l of substrate buffer $\left(13 \mathrm{~g} \mathrm{l}^{-1}\right.$ citric acid, $28 \mathrm{~g} \mathrm{l}^{-1}$ sodium citrate, $1 \mathrm{ml}$ hydrogen peroxide, $0.24 \mathrm{~mm}$ merthiolate and freshly added $1 \mathrm{mg} \mathrm{l}^{-1}$ of $o^{-}$ phenylenediamine as chromogen, adjusted to $\mathrm{pH} 4.8$ ) were added and colorimetric reaction stopped with $50 \mu \mathrm{l}$ per well of $4 \mathrm{M} \mathrm{H}_{2} \mathrm{SO}_{4}$ after $30 \mathrm{~min}$. The results were read in a Titertek Multiskan plate reader at three wavelengths (450, 492 and $620 \mathrm{~nm}$ ) The absorbance at $620 \mathrm{~nm}$ was used to correct for individual non-significant differences between wells. The absorbance at $450 \mathrm{~nm}$ was used to calculate the $492 \mathrm{~nm}$ absorbance values $\geqslant 2$ by approximation (absorbance at $492 \mathrm{~nm}=$ absorbance at $450 \mathrm{~nm} \times 2.4$ ). Sensitivity was calculated with a $95 \%$ confidence level by assuming a normal distribution of background values as suggested by Tijssen (1985).

\section{Addition of viruses to turbot kidney extracts}

Turbot were purchased from commercial farm (mean body weight per fish: $2-3 \mathrm{~kg}$ ). The kidneys were excised and uree kidneys lonnogenized with a Potter homogenizer at $10 \%$ $(w / v)$ in RPMI 1640 medium. After centrifugation at $3000 \times \mathrm{g}$ for $20 \mathrm{~min}$, the supernatants were diluted 1:1 with cell culture supernatants from EPC monolayers previously infected with either VHSV or IPNV (Basurco and Coll, 1989a,b). Final virus concentrations were estimated by the $\mathrm{TCID}_{50}$ method to contain $0.5 \times 10^{6} \mathrm{TCID}_{50} / \mathrm{ml}$ of VHSV and $0.5 \times 10^{7}$ 


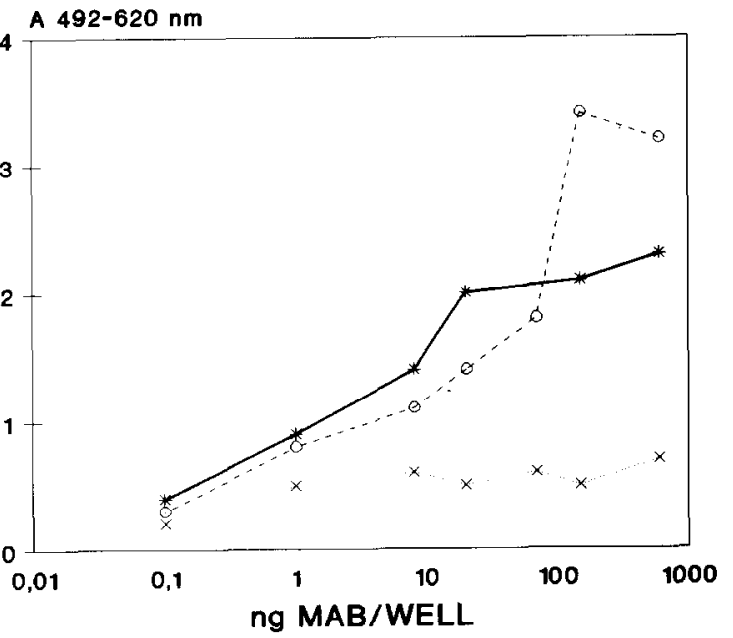

antI-N VHSV IgO $\quad *$ anti-N VHSV $2 \mathrm{CS}$
entI-VP3 IPNV $2 F 12$

FIG. 1. Titration of Mabs used for conjugates. Mabs purified by protein-A Sepharose chromatography were allowed to react at different dilutions with $1 \mu \mathrm{g}$ of purified virus per well. Rabbit anti-mouse immunoglobulin labelled with peroxidase was used to reveal the reaction. — low-affinity Mab.

$\mathrm{TCID}_{50} \mathrm{ML}$ of IPNV. Control extracts were diluted with supernatant from uninfected EPC cultures. The mixtures were stored frozen at $-40{ }^{\circ} \mathrm{C}$ until assayed.

\section{RESULTS}

\section{Selection of Mabs}

To obtain peroxidase conjugates by the one-step aged-glutaraldehyde method (Coll, 1987b), Mabs should have the highest possible titre. Mabs 2C9 for VHSV and 2F12 for IPNV had the highest titres when tested by indirect ELISA over plates coated with their respective purified virus (Fig. 1). After conjugation to peroxidase their titre was maintained (not shown).

Due to the necessity of using both high ionic strength buffers and one-step ELISA to obtain the highest sensitivity with the sandwich ELISA for VHSV, and in order to use a unique protocol for both VHSV and IPNV for simplicity, Mabs anti-IPNV had to be selected from those described (Babín et al., 1990; Domínguez et al., 1990, 1991) that were capable of performing under both conditions mentioned above. Figure 2 shows that the pair of Mabs 2Al (solid-phase) and 2F12 (conjugated to peroxidase) not only performed well under the conditions defined but even slightly increased the intensity of the ELISA.

To be able to screen turbot kidney homogenates with maximum sensitivity, the lowest dilution of homogenates (1:1) had to be used. Therefore to decrease the possible background under those circumstances, the concentration of Tween in the sample 


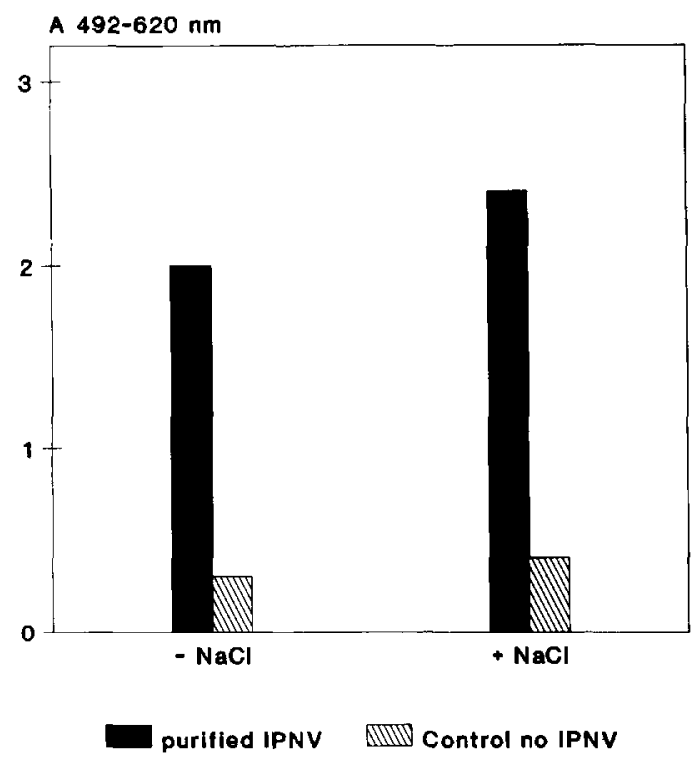

FIG. 2. Sandwich ELISA to detect IPNV by using high ionic strength buffer. The ELISA was performed by using the Mabs 2A1/2F12 in the absence or presence of $1 \mathrm{M} \mathrm{NaCl}$. Averages and standard deviations of duplicates are given. $\mathbf{\square}$, control no IPNV; $\square, 100 \mathrm{ng}$ per well purified IPNV.

dilution buffer was increased from $0.5 \mathrm{~g} \mathrm{l}^{-1}$ to $4 \mathrm{~g} \mathrm{l}^{-1}$. Both ELISA assays performed equally well under the new conditions (not shown).

\section{Analytical variables}

Figure 3 illustrates a typical example (averages and ranges from three different ELISA experiments) of the standard curves for the VHS and the IPNV binding to the Mabscoated solid phases. The linear part of the assays were between 0.6 and 3.0 absorbance units at $492-620 \mathrm{~nm}$, corrresponding to 10-200 ng of virus per well. No hook effect was found up to a maximum concentration of virus of $1000 \mathrm{ng}$ per well. The mean absorbance values of background (in the absence of added virus) varied from experiment to experiment by $0.05-0.1 \pm 25 \%(n=4)$.

Sensitivity was defined as the lowest virus concentration that can be measured over the background to a $95 \%$ confidence level, i.e. assuming a normal distribution varying between absorbances of $0.7-0.15$, which corresponds to about $2-4 \mathrm{ng}$ of virus per well.

Intra-assay coefficients of variation of the absorbance of the standards varied between 3-10\%. Inter-assay ranges depended upon the virus concentration as shown in Fig. 3.

The two pairs of Mabs selected were studied by sandwich ELISA assays with both purified VHSV and IPNV. Experiments showed that each assay was specific for its homogeneous virus.

\section{Assay of TCID $_{50}$ in turbot kidney homogenates}

To define the cut-off between negative and positive samples, homogenates of pooled healthy turbot kidney were prepared and assayed by each of the ELISAs. Values lower 


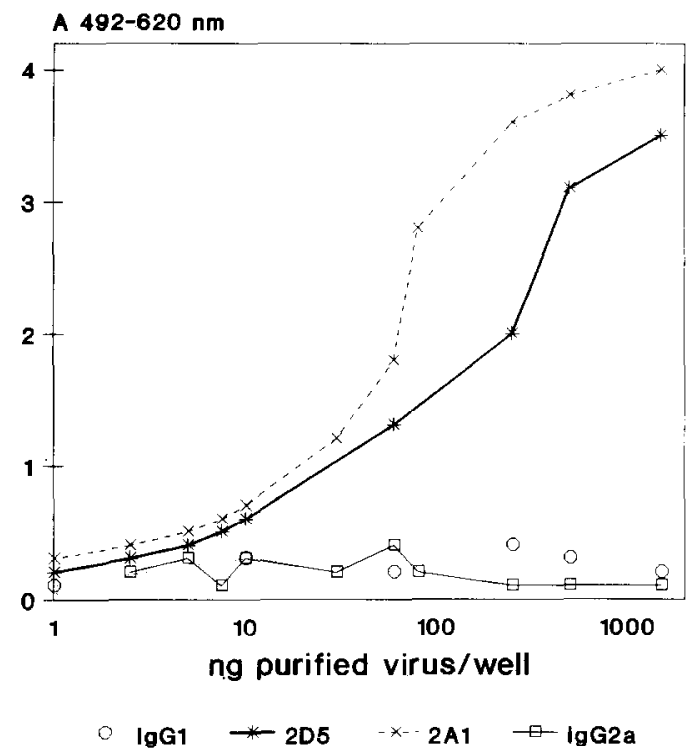

FIG. 3. Comparative standard curves obtained with purified VHSV and IPNV by sandwich ELISA. The means from three different experiments are shown. Plates coated with —— anti-VHSV 2D5 Mab; - - --- , anti-IPNV 2A1 Mab; ….........., irrelevant mouse IgG1 (anti-VHSV9); $\square$, irrelevant mouse IgG2a (anti-IPNV).

than $1000 \mathrm{TCID}_{50}$ per $\mathrm{ml}$ of homogenate could not be considered positives for any of the viruses (Fig. 4). The relationship between $\mathrm{TCID}_{50}$ per well and absorbances by ELISA for each of the viruses are shown in Fig. 4. Background estimates by virus-infected turbot kidney homogenates in plates coated with irrelevant mouse IgG1 or IgG2a showed that the lower the dilution of the homogenate, the higher the background in both VHSV and IPNV. Thus for a minimum two-fold dilution of the homogenate (maximum sensitivity), backgrounds obtained for VSHV or IPNV were about $51 \%$ or $25 \%$, respectively, of the value obtained with plates coated with specific Mabs (Fig. 4) (data not shown referred to Mab anti-IPNV because a lack of statistical meaning and therefore its graphical visualization in a graphic and/or table was not valuable. This means that statistical significative data referred to Mab anti-IPNV was not obtained through experimental trials and therefore its visualization was unsuccessful). However, backgrounds obtained with two-fold diluted turbot kidney homogenates over plates coated with specific Mabs were $\leqslant 0.05 \%$ of the value obtained with virus-infected turbot kidney homogenates.

\section{DISCUSSION}

This report describes the use of Mabs in ELISA to detect VHSV and IPNV with high sensitivity and false positive controls in turbot kidney extracts.

Anti-N (VHSV) and anti-VP3 (IPNV) Mabs have been selected to optimize the ELISA 


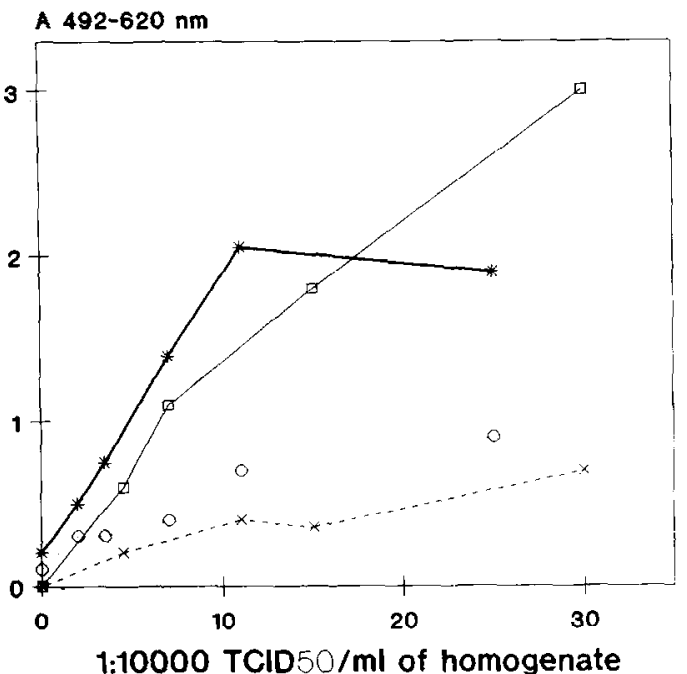

$\circ \lg G 1 \rightarrow 2 D 5-x-\lg G 2 a-2 A 1$

FIG. 4. Relationship between VHSV and IPNV concentrations in turbot kidney homogenates and absorbances by sandwich ELISA. Supernatants from EPC infected with VHSV or IPNV were added to turbot kidney homogenates. Samples were then tested by sandwich ELISA at different homogenate dilutions. VHSV and IPNV were estimated by the TCID50 method: —— kidney homogenates containing VHSV in plates coated with anti-N 2D5 Mab; …........., in plates coated with irrelevant mouse lgG1; _ـ , turbot kidney homogenates containing IPNV in plates coated with anti-VP3 $2 A 1 ;--*--$, in plates coated with irrelevant mouse lgG2a; 0 , turbot kidney homogenates two-fold diluted in plates coated with virus-specific Mabs or irrelevant mouse lgGs.

assay because the $\mathrm{N}$ or the VP3 proteins are the least variable antigens of the rhabdoviruses or birnaviruses, thus this assay could identify the widest range of viral isolates. The epitopes defined by the chosen Mabs were non-competitive and highly conserved in the VHSV (Sanz et al., 1991, results not published) and in the IPNV (Domínguez et al., 1991) serotypes. Furthermore, these proteins are a major component in both the complete virus and infected cells (Basurco et al., 1991).

First attempts to produce ELISA assays for the detection of VHSV with sufficiently high sensitivity were unsuccessful, apparently because the titres of the antisera were too low (Dixon and Hill, 1984). Virus could be detected in cell culture before any cytophatic effect was observed and assays were specific for IHNV or VHSV; however, sensitivity remained a problem (Way and Dixon, 1988) until high ionic strength buffers and Mabs were used (Mourton et al., 1990; Sanz and Coll, 1990). Most probably this is due to nucleocapsid disruption at this high ionic strength; in addition, this contributes to lowering of the background by reducing non-specific binding in both the VHSV and in the IPNV assays. Attempts to use unique buffers and protocols for both viruses were successful and thus the assay was simplified. The use of control plates coated with irrelevant mouse antibodies (IgG1 and IgG2a) in parallel ELISAs allows a precise estimation of possible false positives. The extent of false positive signals depends, among other things, upon the 
final dilution of the turbot kidney homogenate (Fig. 4) and it is only significant for homogenates containing viruses (backgrounds at two-fold homogenate dilutions of $25-51 \%$ compared with $\leqslant 0.05 \%$ ). These facts could be explained by non-specific absorption of the viruses to the plates and could be estimated during each assay by the inclusion of control plates.

In other closely related techniques such as immunodot, tissue extracts or homogenates could not be used because their high protein content clogged the nitrocellulose filter, causing excessive backgrounds (McAllister and Schill, 1986; Schultz et al., 1989; not shown).

One hundred microlitres of homogenate were sufficient for performing the measurements in duplicate. Micro-sample volumes are especially desirable for testing individual turbot juveniles. Samples (entire fish) can be frozen and stored at $-20^{\circ} \mathrm{C}$ before performing the ELISA. Multiple homogenizers for use with 96 well plates can be used to obtain individual homogenates (French-Constant and Devonshire, 1987). In this case the individual homogenates can be transferred with a multichannel pipette to the ELISA solid phase. The time to examine 40 samples can thus be under $4 \mathrm{~h}$ (including both homogenization and proper ELISA).

Once all the precise reagents of ELISA was previously optimized (according to Coll et al. , several publications from 1988 to 1991) it's enough easy to develop a successfully cELISA use, because the main obstacle to obtain the best results with ELISA are those referred to the multiple options and calculations to avoid the background and inespecific signals produced by the use of several reagents not stable chemically and whose management to develop field assays was very difficult.

The assays performed with an improved ELISA kit, according to the methodology indicated above, allow the corroboration of strong visual positive signals corresponding to the quantification of ng of IPNV and VHSV present in the plates (particulary IPNV, Fig. 5) and an absorbance value at $492-620 \mathrm{~nm}$ higher than 2, according to the plate reader. Therefore the trial, under laboratory conditions, was a success and enough of significance to recommend its use in fish farms to monitor the first stages of infection.

\section{CONCLUSIONS}

The binding of solid-phase Mabs of VHSV and IPNV and their subsequent detection provides a non-precipitation, non-agglutination and a non-radioactive alternative for detection of these viruses, with the specific advantages of a non-competitive sandwich ELISA with two monoclonal antibodies (a design more favoured to quantify every pathogen in an infected animal), in this case with the use of identical reagents and protocols, stable reagents, easy automation, wide linear range, high reproducibility, low backgrounds, higher sensitivity than other immunoassay techniques, high precision and low incidence of false positives or negatives. However, the ELISA might not be as sensitive as cell culture for detecting virus-carrying turbot and therefore its use in routine screening is not yet fully advocated. Detection of VHSV or IPNV by ELISA should depend upon the stage of infection (acute/carriers). All these characteristics make this assay suitable for specific virus determination of acute infections in turbot culture. In the future, a panel of different ELISA assays (IPNV, VHSV and IHNV as viruses of main 


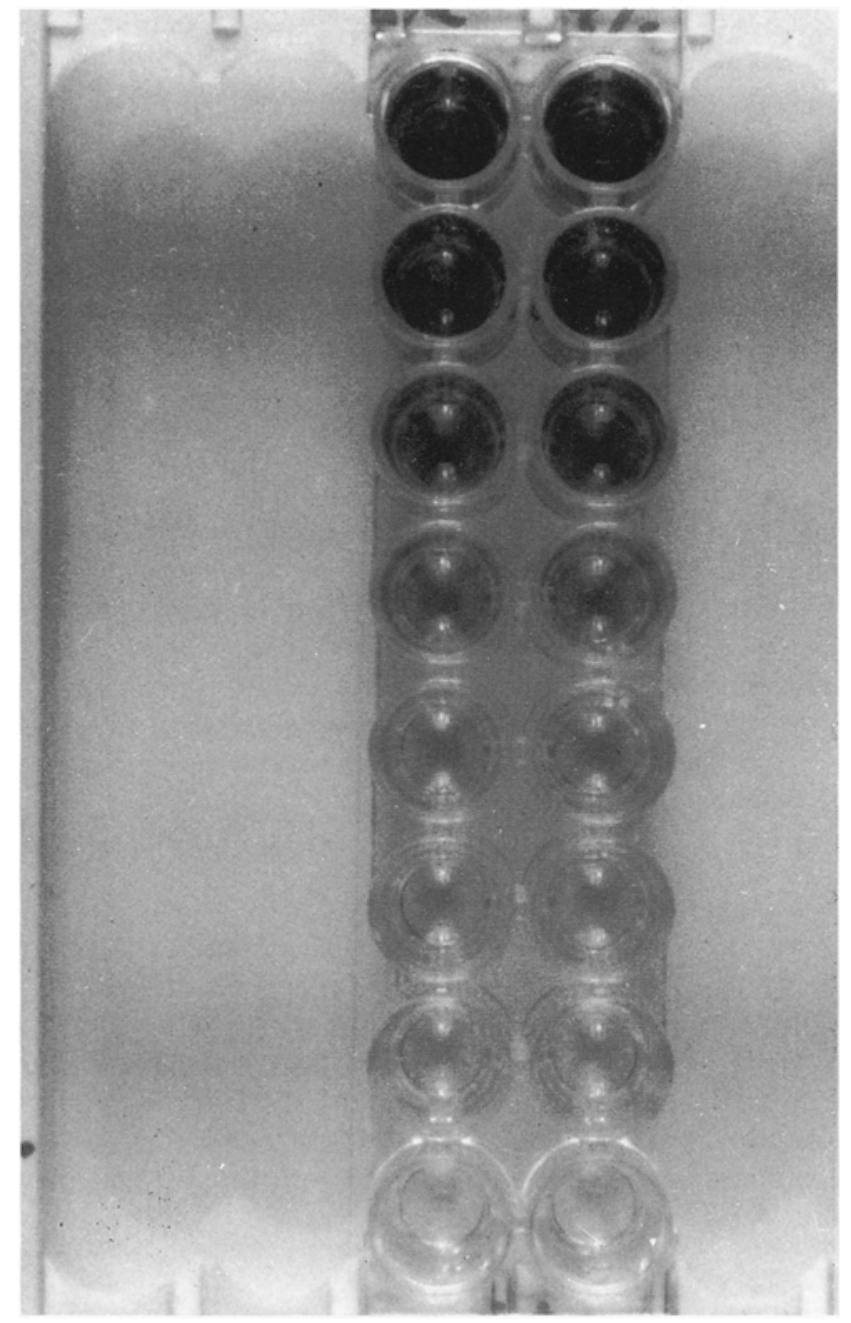

FIG. 5. Sandwich ELISA to detect IPNV. Solid phase coated wtih anti-IPNV 2A1. Method described in text. The last file is coated with negative control IgG2a Mab.

epidemiological interest) could be used to provide both rapid detection and identification of these pathogens (Ristow and Arnzen, 1989, 1991).

\section{ACKNOWLEDGEMENTS}

Thanks are due to Dr J. Domínguez and M. Babín of INIA, for their help with the monoclonal antibodies used in this work. The technical assistance of V. Mogarra, C. Hernández and D. Frías was appreciated. One of the authors (M.V.B.) was a fellow from the Becas para intercambio de personal investigador entre Industrias y OPIs del Ministerio de Educación y Ciencia en España', and is particularly grateful to the Department of Fish Pathology of INIA and the private fish farm ACUIDORO, S.L., Ferrol-La 
Coruña, Spain, for their support in enabling us to carry out these assays. This work was supported by grants 8568 and 8171 from INIA, Ministry of Agriculture, Fish and Food, Spain.

\section{REFERENCES}

Babín, M., Hernández, C., Sánchez, C. and Domínguez, J. (1990) Detección rápida del virus de la NPI por enzimo-inmunoabsorción de captura. Medicina Veterinaria 7, 557-560.

Basurco, B. and Coll, J.M. (1989a) Variabilidad del virus de la septicemia hemorrágical viral de la trucha en España. Medicina Veterinaria 6, 425-430.

Basurco, B. and Coll, J.M. (1989b) Spanish isolates and reference strains of VHSV show similar protein size patterns. Bulletin of the European Association of Fish Pathologists 9, 92-95.

Basurco, B., Sanz, F., Marcotegui, M.A. and Coll, J.M. (1991) The free nucleocapsids of VHSV contain two antigenically related nucleoproteins. Archives in Virology 119 153-163.

Castric, J. and De Kinkelin, P. (1984) Experimental study of the susceptibility of two marine fish species: sea bass (Dicentrarchus labrax) and turbot (Scophthalmus maximus) to viral haemorrhagic septicaemia. Aguaculture 41, 203-212.

Coll, J.M. (1987a) Injection of physiological saline facilitates recovery of ascitic fluids for monoclonal antibody production. Journal of Immunological Methods 104, 219-222.

Coll, J.M. (1987b) Heme increases peroxidase-antibody activity in aged conjugates. Journal of Inmunological Methods 104, 259-263.

Coll, J.M. (1988) Development of a fast solid-phase enzyme immunoassay for C-reactive protein. Revista Española de Fisiología 44, 359-368.

Coll, J.M. (1989) Addition of reducing agents to the peroxidase-o-phenylenediamine buffer reduces background of enzyme-immunoassays. Revista Española de Fisiología 45, 41-46.

Coll, J.M. (1991) Evaluation of commercial reproducible solid-phase enzyme immunoassays. Immunología 10, 73-85.

Dixon, P.F. and Hill, B.J. (1984) Rapid detection of fish rhabdoviruses by the enzyme-linked immunosorbent assay (ELISA). Aquaculture 42, 1-12.

Domínguez, J., Hedrick, R.P. and Sánchez-Vizcaíno, J.M. (1990) Use of monoclonal antibodies for detection of infectious pancreatic necrosis virus by the enzyme-linked immunosorbent assay (ELISA). Diseases of Aquatic Organisms 8, 157-163.

Domínguez, J., Babín, M., Sánchez, C. and Hedrick, R.P. (1991) Rapid serotyping of infectious pancreatic necrosis virus by one-step enzyme linked immunosorbent assay using monoclonal antibodies. Journal of Virological Methods 31, 93-104.

French-Constant, R.H. and Devonshire, A.L. (1987) A multiple homogenizer for the rapid preparation of samples for immunoassays and electrophoresis. Biochemical Genetics 25, 4748.

Martínez, J. and Coll, J.M. (1987) Preliminary clinical studies of C-reactive protein quantified by enzyme-linked immunoassays. Clinical Chemistry 33, 2185-2190.

Martínez, J. and Coll, J.M. (1988) Selection and clinical performance of monoclonal anti-C reactive protein in ELISA quantitative assay. Clinical Chemistry Acta 176, 123-132.

McAllister, P.E. (1988) Infecciones víricas de peces cultivados. In: Patología in Acuicultura (eds J. Espinosa de los Monteros and U. Labarta) Ed. CICYT, Spanish Government, Madrid, Spain, pp: 85.

McAllister, P.E. and Schill, W.R. (1986) Immunoblot assay: a rapid and sensitive method for identification of salmonid fish viruses. Journal of Wildlife Diseases 22, 468-474.

Mourton, C., Bearzotti, M., Piechaczyk, M., Paolucci, F., Pau, B., Bastide, J.M. and De Kinkelin, P. (1990) Antígen-capture ELISA for viral haemorrhagic septicaemia virus serot. I. Journal of Virological Methods 29, 325-334.

Ristow, S.S. and Arnzen, J.M. (1989) Development of monoclonal antibodies that recognize a type-2 
specific and a common epitope on the nucleoprotein of infectious hematopoietic necrosis virus. Journal of Aquatic Animal Health 1, 119-125.

Ristow, S.S. and Arnzen, J.M. (1991) Monoclonal antibodies to the glycoprotein and nucleoprotein of infectious hematopoietic necrosis virus (IHNV) reveal differences among isolates of the virus by fluorescence, neutralization and electrophoresis. Diseases of Aquatic Organisms 11, 105-115.

Sanz, F. and Coll, J.M. (1990) Mayor eficacia y sensibilidad en el diagnóstico de rhabdovirus. Biotecnología 6, 7-9.

Sanz, F. and Coll, J.M. (1993) Detection of viral haemorrhagic septicaemia rhabdovirus by ELISA using two non competitive monoclonal antibodies to the early nucleoproteins at high salt concentration. American Journal of Veterinary Research (unpublished).

Schlotfeldt, H.J., Ahne, W., Vestergard-Jorgensen, P.E. and Glende, W. (1991) Occurrence of viral haemorrhagic septicaemia in turbot (Scophthalmus maximus L) - A natural outbreak. Bulletin of the European Association of Fish Pathologists 11, 105-107.

Schultz, C.L., McAllister, P.E., Schill, W.B., Lidgerding, B.C. and Hetrick, F.M. (1989) Detection of infectious hematopoietic necrosis virus in cell culture fluid using immunoblot assay and biotinylated monoclonal antibody. Diseases of Aquatic Organisms 7, 31-37.

Tijssen, P. (1985) Practice and theory of enzyme immuno-assays. In: Laboratory Techniques in Biochemistry and Molecular Biology: practice and theory of enzyme immunoassay (eds, R.H. Burdon and P.H. Knippenberg) Elsevier: Amsterdam, chapter 15 (from page 385).

Way, K. and Dixon, P.F. (1988) Rapid detection of VHS and IHN viruses by the enzyme-linked immunosorbent assay (ELISA). Journal of Applied Ichthyology 4, 182-189. 